\title{
ARTICLE
}

\section{Estimates of Food Consumption Rates for Invasive Blue Catfish}

\author{
Joseph D. Schmitt* \\ U.S. Geological Survey, Great Lakes Science Center, Lake Erie Biological Station, 6100 Columbus Avenue, Sandusky, \\ Ohio 44870, USA
}

\author{
Corbin D. Hilling 1 (D) and Donald J. Orth \\ Department of Fish and Wildlife Conservation, Virginia Polytechnic Institute and State University, 106 Cheatham Hall, \\ Blacksburg, Virginia 24060, USA
}

\begin{abstract}
As a prolific invasive species, Blue Catfish Ictalurus furcatus threaten native organisms in numerous estuarine and tidal freshwaters along the Atlantic coast of the United States. However, no published estimates of consumption rates are available for Blue Catfish in the scientific literature. This information is critical for development of bioenergetics models or estimation of population-level impacts on native species. Using a combination of field and laboratory studies, we provide the first estimates of daily ration, maximum daily ration, and consumption to biomass ratios for Blue Catfish populations. Ad libitum feeding trials conducted in our laboratory reveal that maximum daily ration in Blue Catfish varies by prey type, temperature, and fish size, with maximal feeding occurring in medium-sized Blue Catfish $\left(500-600 \mathrm{~mm}\right.$ total length) and at temperatures $\geq 15^{\circ} \mathrm{C}$. Furthermore, estimates of daily ration were higher for fish prey (Gizzard Shad Dorosoma cepedianum) than for crustacean prey (blue crab Callinectes sapidus). Diel feeding chronologies based on field-collected diet samples from 1,226 Blue Catfish demonstrated river-specific variability in daily ration and maximum daily ration. Blue Catfish daily ration ranged between $2.27 \%$ and $5.22 \%$ bodyweight per $24 \mathrm{~h}$, while maximum daily ration ranges between $8.56 \%$ and $9.37 \%$ bodyweight per $24 \mathrm{~h}$. Estimates of consumption to biomass ratios varied by river and Blue Catfish size groupings but range between $\mathbf{2 . 4 2}$ and 3.39, which is similar to other benthic omnivores. This research will inform the assessment of predatory impacts of invasive Blue Catfish in the Chesapeake Bay and beyond as it will enable researchers to estimate predatory impacts through the coupling of population models, food habit information, and consumption rate information (current study).
\end{abstract}

Over the past two decades, invasive species have been increasingly recognized as a major threat to global biodiversity (Lockwood et al. 2013) and are major drivers of global change (Garcia-Berthou 2007). Invasive species can impact native biota through predation and competition or indirectly through the spread of novel diseases and parasites. Because of this, invasions can cause changes in food web structure, which can alter ecosystem function (Mack et al. 2000; Clavel et al. 2011).
Freshwater habitats are some of the most invaded ecosystems on earth (Clavero and Garcia-Berthou 2006), and more studies on the biology of invasive freshwater fishes are "urgently needed" (Garcia-Berthou 2007) as it will aid in the development of more effectual management strategies.

Blue Catfish Ictalurus furcatus are native to the Mississippi River and several Gulf of Mexico tributaries and are the fourth largest freshwater fish in North America

\footnotetext{
*Corresponding author: jschmitt@usgs.gov

${ }^{1}$ Present address: U.S. Fish and Wildlife Service, Maine Field Office, 306 Hatchery Road, East Orland, Maine 04431, USA.

Received August 6, 2020; accepted January 19, 2021
} 
(Graham 1999). Blue Catfish have been widely stocked as a sport and food fish, and nonindigenous populations now occur in many Atlantic slope drainages from Maryland to Georgia (Moser and Roberts 1999; Schloesser et al. 2011; Bonvechio et al. 2012). Populations are remarkably dense in Chesapeake Bay tributaries, with tagging studies in relatively small areas estimating densities from 239 to 708 Blue Catfish per hectare (Fabrizio et al. 2017; Bunch et al. 2018). Due to rapid population expansion, high population densities, and their potential to impact native biota, Blue Catfish are now considered invasive along the Atlantic slope (ASMFC 2011), and further range expansion is likely (Nepal and Fabrizio 2019).

One potential mechanism of ecosystem impact by invasive species is through predation on native species. In wild populations, estimation of predatory impacts requires an understanding of consumption rates (Ney 1990; Cerino et al. 2013), and estimates for Blue Catfish do not currently exist in the scientific literature. Consumption estimates are important for understanding fish foraging rates and community dynamics (Vigg et al. 1991) and are essential for the construction of ecosystem models (Christensen and Walters 2004) and bioenergetics models (Deslauriers et al. 2017). Considering this, our major objective was to provide estimates of daily ration, maximum daily ration, and consumption per unit biomass for all sizes of Blue Catfish using a combination of field experiments, lab experiments, and empirical regression models (e.g., Palomares and Pauly 1998).

\section{METHODS}

Laboratory estimates of maximum daily ration.-Fifteen Blue Catfish ranging from 332 to $878 \mathrm{~mm}$ total length (TL) were collected from the Rappahannock River $\left(38^{\circ} 09^{\prime} 42.4^{\prime \prime} \mathrm{N}, 77^{\circ} 03^{\prime} 48.0^{\prime \prime} \mathrm{W}\right)$ in October of 2015 with high-frequency electrofishing $(60 \mathrm{~Hz})$ using a 7.5 GPP Midwest Lakes electrofishing system. Most of the Blue Catfish ranged from 332 to $500 \mathrm{~mm}$ TL $(N=11)$, though four large $(>500 \mathrm{~mm} \mathrm{TL})$ fish were also collected. Fish were transported to the Virginia Tech Freshwater Mussel Conservation Center in a cool, aerated live well, and upon arrival, they were placed within two aquaria with shared biofiltration and digital temperature control systems. The first tank was $167 \mathrm{~cm}$ long $\times 167 \mathrm{~cm}$ wide $\times 102$ $\mathrm{cm}$ deep and held approximately $2,800 \mathrm{~L}$ of water-this tank was used for the large Blue Catfish (>500 mm TL). A second, round tank was used for smaller individuals $(<500 \mathrm{~mm} \mathrm{TL})$ and had a diameter of $107 \mathrm{~cm}$ and a height of $107 \mathrm{~cm}$. This tank held approximately $950 \mathrm{~L}$ of water. Salinity within the recirculating aquaculture system was kept within $\pm 0.5 \%$ of the salinity recorded at the time of capture $(3.0 \%)$ using evaporated solar salt. Fish were allowed to acclimate for 4 weeks prior to any experimentation (Bourret et al. 2008), and acclimation conditions included a $14 \mathrm{~h}$ light $: 10 \mathrm{~h}$ dark photoperiod, a constant water temperature of $13^{\circ} \mathrm{C}$, and biweekly rations $(\approx 5 \%$ of their bodyweight) of fresh Gizzard Shad Dorosoma cepedianum.

Fish size, prey type, and water temperature have been demonstrated to be the major drivers of fish daily consumption, while other factors, such as salinity, have little impact on consumption (Bromley and Last 1990; Temming and Andersen 1992). Given this, maximum daily ration was estimated at three temperatures $(5,15$, and $25^{\circ} \mathrm{C}$ ) with two prey types (Gizzard Shad and blue crab Callinectes sapidus) for Blue Catfish ranging from 332 to $878 \mathrm{~mm}$ TL. The temperature range chosen was very close to the range of water temperatures regularly observed in the Chesapeake Bay $\left(4^{\circ} \mathrm{C}\right.$ to $28^{\circ} \mathrm{C}$; Shiah and Ducklow 1994). Partitions were installed in each tank so that each fish had their own enclosure, and fish were allowed to acclimate to each experimental temperature for $14 \mathrm{~d}$. Temperature adjustments between experiments did not exceed $2^{\circ} \mathrm{C}$ per day (Hayward and Arnold 1996). Prior to trials, Blue Catfish were starved for $72 \mathrm{~h}$ to ensure empty stomachs (Amundsen and Klemetsen 1988).

To determine laboratory maximum consumption $\left(C_{\mathrm{Lmax}}\right)$, Blue Catfish were fed ad libitum rations of Gizzard Shad or blue crab for $24 \mathrm{~h}$, with old food being removed and new food added every $3 \mathrm{~h}$, with weights recorded for each food item that was added or removed (Bourret et al. 2008). Six different combinations of feeding trials were completed: one for each prey type (Gizzard Shad and blue crab) at each temperature $(5,15$, and $25^{\circ} \mathrm{C}$ ). Furthermore, a total of three replicates were completed for each treatment combination. Food items were either fresh (within $2 \mathrm{~d}$ of capture) or previously frozen, as freezing does not significantly alter evacuation rates (Andersen 2012). However, Gizzard Shad were kept on ice and frozen promptly after capture to prevent degradation. Blue Catfish were kept within individual enclosures, so maximum daily consumption was estimated by subtracting the weight of uneaten food from the total weight of food given to each individual fish. All Blue Catfish were weighed at the beginning and end of each experimental test period (Bourret et al. 2008).

Laboratory analysis. - Blue Catfish varied in weight over the course of the experiment since the same fish were used in multiple trials and substantial weight gain occurred due to ad libitum feeding. To make consumption rates comparable among temperatures and prey types, we used a weight-standardized approach to correct for variation in body size (Hayward and Arnold 1996; Zwiefel et al. 1999). For each individual fish, maximum daily consumption was adjusted to a standardized body weight of $3,455 \mathrm{~g}$, which is the mean body weight recorded for all fish throughout the 
experiment (Hayward and Arnold 1996; Zweifel et al. 1999). To weight-standardize daily consumption rates, the allometric equation $C_{\mathrm{Lmax}}=a W^{b}$ was used to calculate weight-specific maximum daily ration, where $W$ is the body weight (g) of the fish and $a$ and $b$ are regression constants. A value of -0.31 was used for $b$ (Hansen et al. 1997), while the dummy value of 1 was used for $a$ (Zwiefel et al. 1999). The mean weight for each fish within each experimental trial was added to the allometric equation, and the resulting $C_{\mathrm{Lmax}}$ was divided by the $C_{\mathrm{Lmax}}$ value for the grand mean of all fish weights (3,455 g; Bourret et al. 2008). All prey- and temperature-specific consumption values $(\mathrm{g} / \mathrm{d})$ were adjusted to body weight using the above weight-standardized quotient (Bourret et al. 2008). Differences in weight-adjusted daily consumption among temperatures, prey types, and fish total length were tested using a univariate, repeated measures analysis of variance (ANOVA) because the same fish were reused in subsequent treatments (Green 1993). Before proceeding with ANOVA, the data were tested for normality (Shapiro-Wilk test), for heteroscedasticity (Levene's test), and for sphericity (Mauchly's sphericity test). Normality and equal variance assumptions were not initially met, so a logit transformation was used (Warton and Hui 2011). Subsequent tests revealed that assumptions were satisfied. Significance was evaluated with an effective alpha $(\alpha)=0.05$. When significant effects were detected, post hoc Tukey's multiple comparisons (using a Bonferroni correction) were used to further explore pairwise differences in consumption rate (Bourret et al. 2008). All analyses were performed in the programming language $\mathrm{R}$ ( $\mathrm{R}$ Core Team 2018).

Field estimates of consumption.-Fish feeding behavior can be highly structured by the diel cycle (Johnson and Dropkin 1993), and many species of fish exhibit clear diurnal behavioral patterns (Helfman 1993). We conducted 24-h feeding chronologies with 3-h sampling intervals during the summers of 2013, 2014, and 2015 to determine consumption rates and diel variation in Blue Catfish feeding patterns. Because 24-h feeding chronologies require some degree of operation in complete darkness, we chose areas on the James, Pamunkey, Mattaponi, and Rappahannock rivers (Figure 1) that support high densities of Blue Catfish but have fewer hazards than other areas (e.g., we avoided upstream areas with shallow water and strainers or downstream areas that are more susceptible to wave action). Diel feeding patterns were determined for each river during the summer months as low-frequency electrofishing for Blue Catfish works best at water temperatures $>18^{\circ} \mathrm{C}$ (Bodine and Shoup 2010). In addition to improving our understanding of Blue Catfish feeding patterns, diel feeding chronologies will help future researchers maximize the amount of information gained per fish collected as they can sample during times when stomachs are fullest (Bowen 1996).

Field data collected from our diel feeding chronologies were also used to estimate gastric evacuation rates, daily ration, and maximum daily ration. Field estimation of daily ration is preferred as fish are subject to natural conditions (Jarre et al. 1991; Bromley 1994; Grant and Kott 1999). Daily ration and maximum daily ration were estimated using the model developed by Elliot and Persson (1978) as this approach has been used for other catfish species (family Ictaluridae; Baumann and Kwak 2011). While this model may not be the best choice for exclusively piscivorous fish (Héroux and Magnan 1996), Blue Catfish in Virginia's tidal rivers exhibit a broad, omnivorous diet (Schmitt et al. 2017, 2019a, 2019b). Additionally, the Elliot and Persson (1978) model is most effective in the field when sample intervals are $3 \mathrm{~h}$ or less (Cochran and Adelman 1982; Kwak et al. 1992). Fish were sampled at 3-h intervals over a 24-h period from the James, Pamunkey, Mattaponi, and Rappahannock rivers, and diet contents were extracted immediately using pulsed gastric lavage. Gut fullness was calculated for each fish as the wet weight of the stomach contents divided by the wet weight of the fish (Hyslop 1980).

Field analysis. - Daily ration $\left(C_{24}\right)$ was calculated as

$$
C_{24}=\sum_{t=1}^{P} \frac{\left(F_{t+1}-F_{t} \mathrm{e}^{-R T}\right)}{1-\mathrm{e}^{-R T}},
$$

where $F_{t}$ is the mean stomach fullness at time $t, F_{t+1}$ is the stomach fullness at time $t+1, R$ is the gastric evacuation rate for each interval, $T$ is the time interval between samples $(3 \mathrm{~h})$, and $p$ is the number of sampling intervals in a 24 -h period (8). The gastric evacuation rate $(R)$ was first calculated for each 3-h time interval using the slope of stomach fullness $\left(F_{t}\right)$ plotted against time,

$$
R=\frac{\log _{e} F_{t+1}-\log _{e} F_{t}}{T}
$$

where $F_{t}$ and $F_{t+1}$ are the mean stomach fullness at the beginning and end of each interval, respectively (Boisclair and Leggett 1988; Héroux and Magnan 1996). The gastric evacuation rate $(R)$ with the steepest slope was used for modeling maximum daily ration $\left(C_{\max }\right)$, where this maximal value of $R$ is applied to all intervals (Boisclair and Leggett 1988; Héroux and Magnan 1996). Conversely, daily ration $\left(C_{24}\right)$ was estimated using the average gastric evacuation rate calculated from the entire $24-\mathrm{h}$ time series.

Consumption to biomass ratios. - Consumption to biomass $(Q / B)$ estimates provide a measure of food ingested $(Q)$ per biomass of a population $(B)$ over a period of time, usually 1 year (Palomares and Pauly 1998; Christensen et al. 2005). We estimated $Q / B$ rates for Blue 


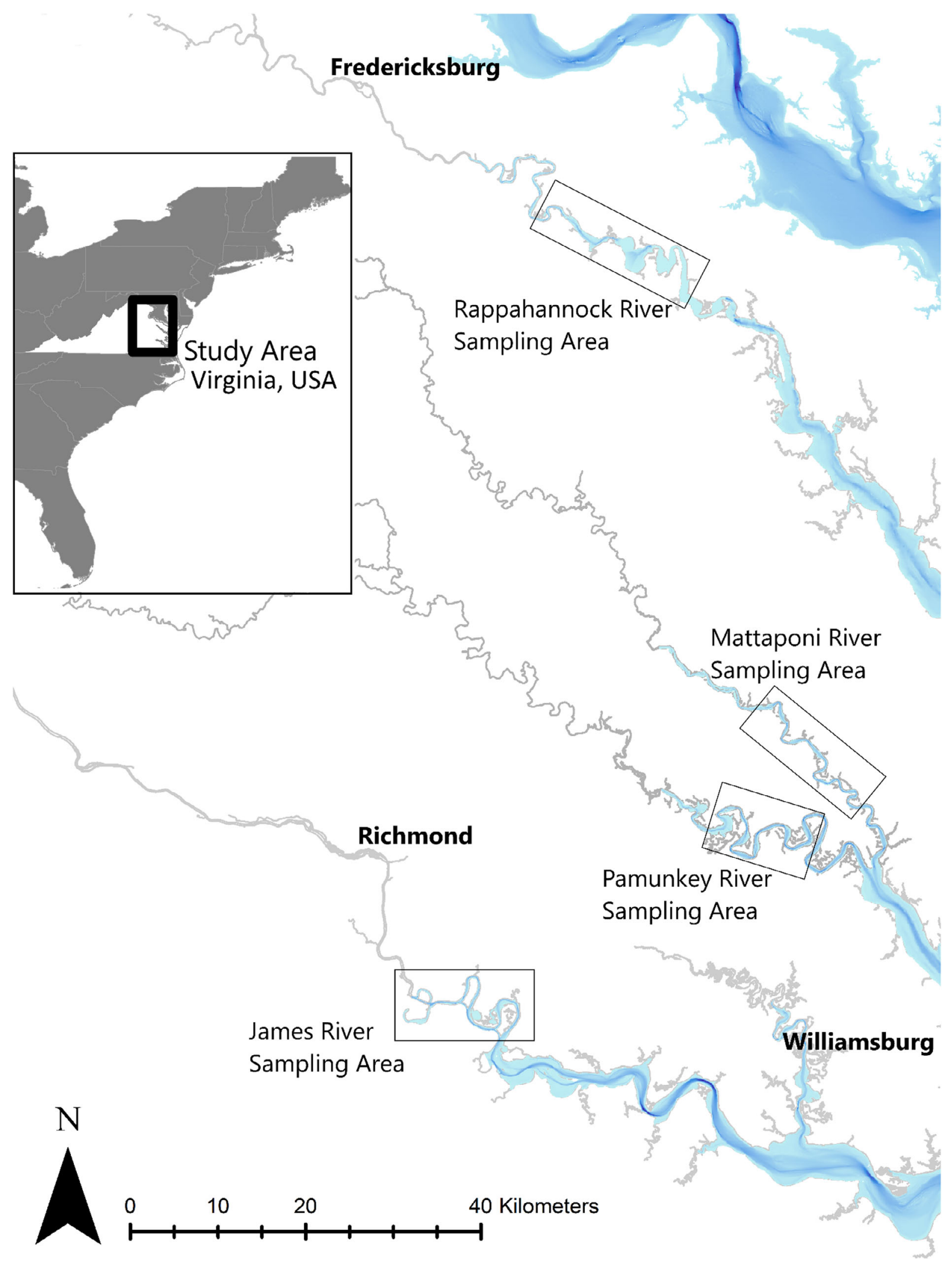

FIGURE 1. Locations for 24-h diel feeding chronology studies to estimate Blue Catfish consumption rates and feeding rhythms in the James, Pamunkey, Mattaponi, and Rappahannock rivers of eastern Virginia. 
Catfish in Virginia's tidal rivers based on an empirical regression model developed by Palomares and Pauly (1998). This regression model was based on lab and fieldbased estimates of consumption for 108 fish populations, including 38 different species and several catfishes (Palomares and Pauly 1998). The following model was used to estimate $Q / B$ :

$$
\begin{aligned}
\log _{10}(Q / B)= & 7.964+0.204\left(\log W_{\infty}\right)-1.965\left(T^{\prime}\right) \\
& +0.083(A)+0.532(h)+0.398(d),
\end{aligned}
$$

where $W_{\infty}$ is the average maximum weight $(\mathrm{g}), T^{\prime}$ is the mean annual water temperature (expressed as $1,000 /{ }^{\circ} \mathrm{K}$ ), $A$ is the aspect ratio of the caudal fin, $h$ is a dummy variable explaining food type $(1=$ herbivore, $0=$ for nonherbivores), and $d$ is a dummy variable also explaining food type $(1=$ detritivores, $0=$ nondetritivores; Palomares and Pauly 1998). The $Q / B$ estimates were calculated separately for smaller, omnivorous fish and for larger, piscivorous fish in each river by including or excluding $h$ and $d$ terms (note: " $d$ " term was only applied to small fish from the James and Rappahannock rivers, where detritus was commonly found in stomachs; Schmitt et al. 2019b). Herbivory and detritivory terms were dropped for piscivorous sizes of Blue Catfish based on studies that demonstrated ontogenetic shifts from omnivory to piscivory, which occur between 500 and $900 \mathrm{~mm} \mathrm{TL}$, depending on river (Schmitt et al. 2019b).

Model parameters. - River-specific estimates for Blue Catfish $W_{\infty}$ were used within each $Q / B$ estimator based on von Bertalanffy growth curves (Orth et al. 2017). Mean annual water temperature $(T)$ was calculated for all segments (tidal fresh, oligohaline, and mesohaline) of the James, Pamunkey, Mattaponi, and Rappahannock rivers using Chesapeake Bay Program water data for 2010-2016 (CBP 2017). Temperatures were averaged by month, and then these values were averaged across all years. Aspect ratio, an index of fish activity level, was determined by (1) removing caudal fins from 27 Blue Catfish (captured in the James River) ranging from 314 to $887 \mathrm{~mm} \mathrm{TL}$, (2) tracing those caudal fins onto paper, and (3) scanning them into a digital database. Aspect ratio was then calculated using TpsDig 2.32, which is freeware specifically developed for geometric morphometric analysis (Rohlf 2016). The mean caudal fin aspect ratio was incorporated into all $Q / B$ estimates.

\section{RESULTS}

\section{Laboratory Estimates of Consumption}

Blue Catfish consumption rates varied significantly with temperature, prey type, and fish size $(P<0.01)$. Across all treatment combinations, laboratory estimates of maximum daily ration $\left(C_{\mathrm{Lmax}}\right)$ varied from $4 \%$ to $21 \%$ of their body weight per $24 \mathrm{~h}(\mathrm{bw} / 24 \mathrm{~h})$, with a grand mean of $9.56 \%$ bw/24 h. The term " $C_{\mathrm{Lmax}}$ " varied significantly with temperature, prey type, and fish total length, though interactions were insignificant (Table 1). On average, Blue Catfish can consume significantly more Gizzard Shad than blue crab in a 24-h period (Figure 2). Consumption rates increase with temperature from $5^{\circ} \mathrm{C}$ to $15^{\circ} \mathrm{C}$, though consumption rates did not differ significantly from $15^{\circ} \mathrm{C}$ to $25^{\circ} \mathrm{C}$ (Tukey's honestly significant difference: $P>0.05$ ). Mean $C_{\text {Lmax }}$ was $7.53 \% \mathrm{bw} / 24 \mathrm{~h}$ consumed at $5^{\circ} \mathrm{C}, 10.66 \%$ $\mathrm{bw} / 24 \mathrm{~h}$ at $15^{\circ} \mathrm{C}$, and $10.55 \% \mathrm{bw} / 24 \mathrm{~h}$ at $25^{\circ} \mathrm{C}$. Consumption rates also differed significantly with fish size, and intermediate-sized Blue Catfish (500-600 mm TL) consumed the most food over a 24-h period (Figure 3). This may be a result of individual feeding behavior due to only one representative fish per length-class for fish $>500 \mathrm{~mm}$ $\mathrm{TL}$, which is discussed below.

\section{Field Estimates of Consumption}

Stomach contents were extracted from 1,226 Blue Catfish on the James, Pamunkey, Mattaponi, and Rappahannock rivers. All diel feeding chronologies were completed in August, and water temperature at all sites ranged from $22.3^{\circ} \mathrm{C}$ to $29.6^{\circ} \mathrm{C}$, which should correspond with maximal, asymptotic consumption rates based on the results from our laboratory study. The time of peak feeding varied by river (Figure 4). Peak feeding occurred at 1500 hours for the James River, at 0900 hours for the Pamunkey River, and at 1200 hours for the Rappahannock and Mattaponi rivers (Figure 4). Field estimates of $C_{\max }$ varied by river, ranging from $4.34 \% \mathrm{bw} / 24 \mathrm{~h}$ in the Mattaponi River to $15.00 \%$ bw/24 h in the Pamunkey River (Table 2). Similar patterns were observed for daily ration, where $C_{24}$ ranged from $2.27 \%$ in the Mattaponi River to $5.22 \%$ in the Pamunkey River (Table 2). Estimates of maximum daily ration from lab experiments $(9.56 \% \mathrm{bw} / 24 \mathrm{~h})$ versus the field experiments $(8.76 \% \mathrm{bw} / 24 \mathrm{~h})$ were remarkably close and did not differ significantly (ANOVA; Figure 5).

TABLE 1. For laboratory experiments, a univariate, repeated-measures ANOVA was used to test for the effects of temperature, prey type, fish length, and interactions on the consumption rates of Blue Catfish (percent body weight per $24 \mathrm{~h}$ ), where the individual fish was treated as the subject. Summary statistics are presented in the table, and the adjusted $R^{2}=0.86$.

\begin{tabular}{lcrc}
\hline Factors & df & \multicolumn{1}{c}{$F$} & $P$ \\
\hline Global model & 8 & 44.10 & $<0.01$ \\
Temperature & 2 & 8.80 & $<0.01$ \\
Prey type & 1 & 11.19 & $<0.01$ \\
Length & 5 & 39.78 & $<0.01$ \\
All interactions & & & $>0.05$ \\
\hline
\end{tabular}




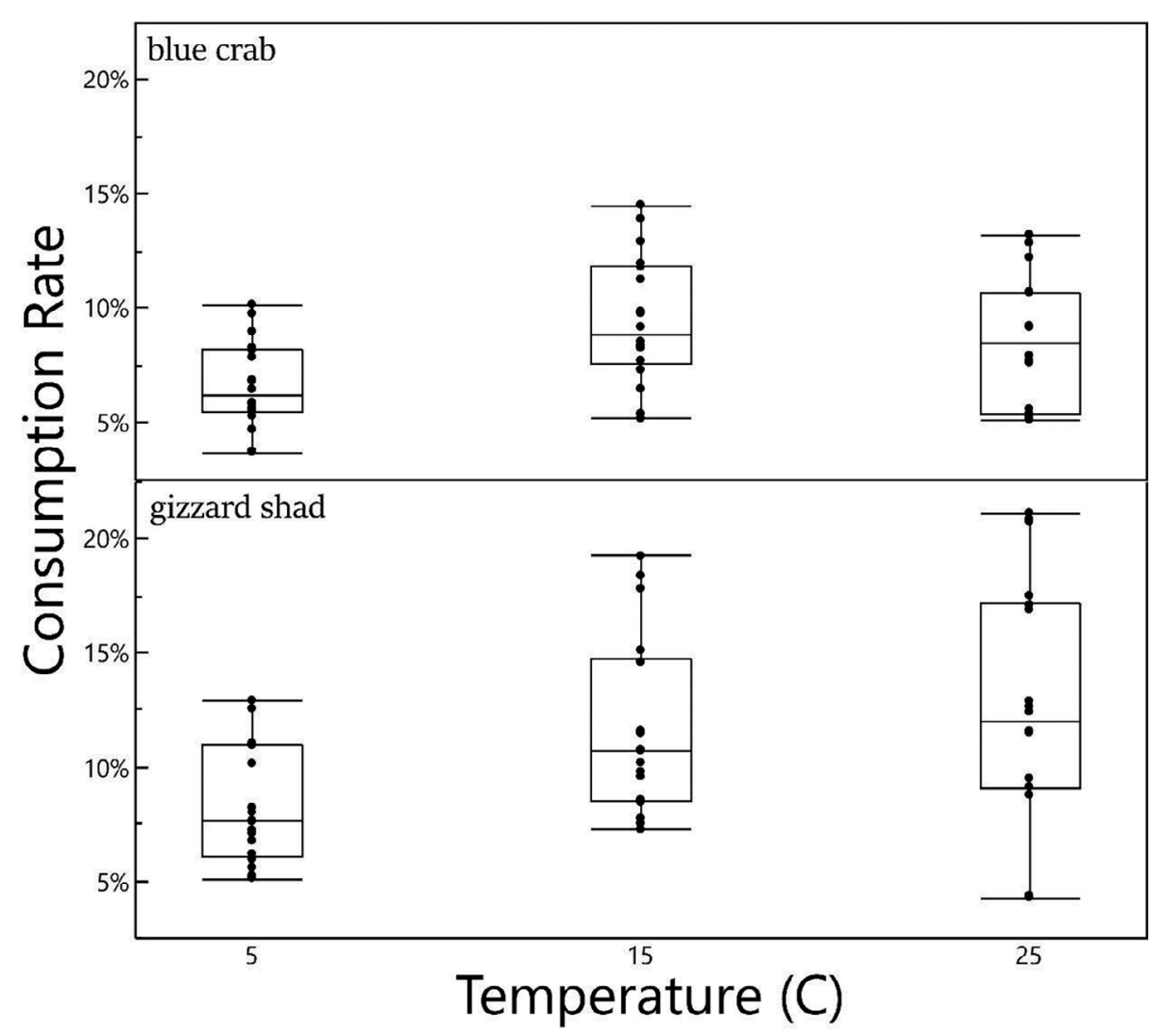

FIGURE 2. Lab estimates of maximum consumption rate (expressed as percent body weight per $24 \mathrm{~h}$ ) for Blue Catfish as it varies by temperature and prey type. Temperature and prey type significantly influenced maximum daily ration $(P<0.01)$. In general, Blue Catfish ate less blue crab than Gizzard Shad in a 24-h period, and consumption rates increased significantly from $5^{\circ} \mathrm{C}$ to $15^{\circ} \mathrm{C}$, with little change occurring from $15^{\circ} \mathrm{C}$ to $25^{\circ} \mathrm{C}$. For the box plots, the horizontal line in each box indicates the median, the box dimensions indicate the 25 th to 75 th percentile ranges, the error bars indicate the 5th to 95th percentile ranges, and the black dots are each individual measurement.

\section{Empirical Estimates of Consumption to Biomass Ratios}

Mean annual water temperatures varied little by river, ranging from $16.89^{\circ} \mathrm{C}$ for the Rappahannock River to $17.23^{\circ} \mathrm{C}$ for the James River. Asymptotic weight $\left(W_{\infty}\right)$ was more variable, ranging from $30.11 \mathrm{~kg}$ for the Pamunkey and Mattaponi rivers to $46.77 \mathrm{~kg}$ for the James River. Consumption to biomass ratios ranged from 2.42 for large fish in the Mattaponi River to 3.39 for small fish in the James River (Table 3). Consumption to biomass ratios also varied in each river, depending on the size of the Blue Catfish $(Q / B$ range for James River $=2.46-3.39, Q / B$ range for Pamunkey River $=2.43-2.96, Q / B$ range for Mattaponi River $=2.42-2.95, Q / B$ range for Rappahannock River $=2.43-3.36$ ). Small omnivorous fish had the highest $Q / B$ values, particularly fish from the James and Rappahannock rivers. This was due to the inclusion of both herbivory and detritivory terms in these river-specific models (Table 3), based on evidence that small Blue Catfish in these rivers routinely consume both detritus and vegetation (Schmitt et al. 2019b). For larger, piscivorous Blue Catfish, the $Q / B$ ratios varied little across rivers, ranging from 2.42 in the Mattaponi River to 2.46 in the
James River. This pattern was driven primarily by differences in $W_{\infty}$, though subtle differences in average annual water temperature also played a role (Table 3 ).

\section{DISCUSSION}

Maximum daily ration of Blue Catfish varied significantly with temperature, prey type, and fish size. Blue Catfish consumed more Gizzard Shad than blue crab in a 24-h period, a pattern that has been demonstrated in several other studies, as the presence of an exoskeleton slows digestion (see Bromley 1994). Blue Catfish maximum daily ration increased with temperature up to $15^{\circ} \mathrm{C}$ yet did not change significantly at $25^{\circ} \mathrm{C}$. Fish consumption rates generally increase with temperature, often reaching an asymptote at higher temperatures (Bromley 1994). Maximum daily ration also varied with fish size, yet there is a strong possibility that this is due to individual behavior as we only had single representative fish within the larger lengthclasses. Two Blue Catfish (500 and $600 \mathrm{~mm} \mathrm{TL}$ ) would gorge themselves to the point at which they could no longer maintain vertical orientation and would lay 


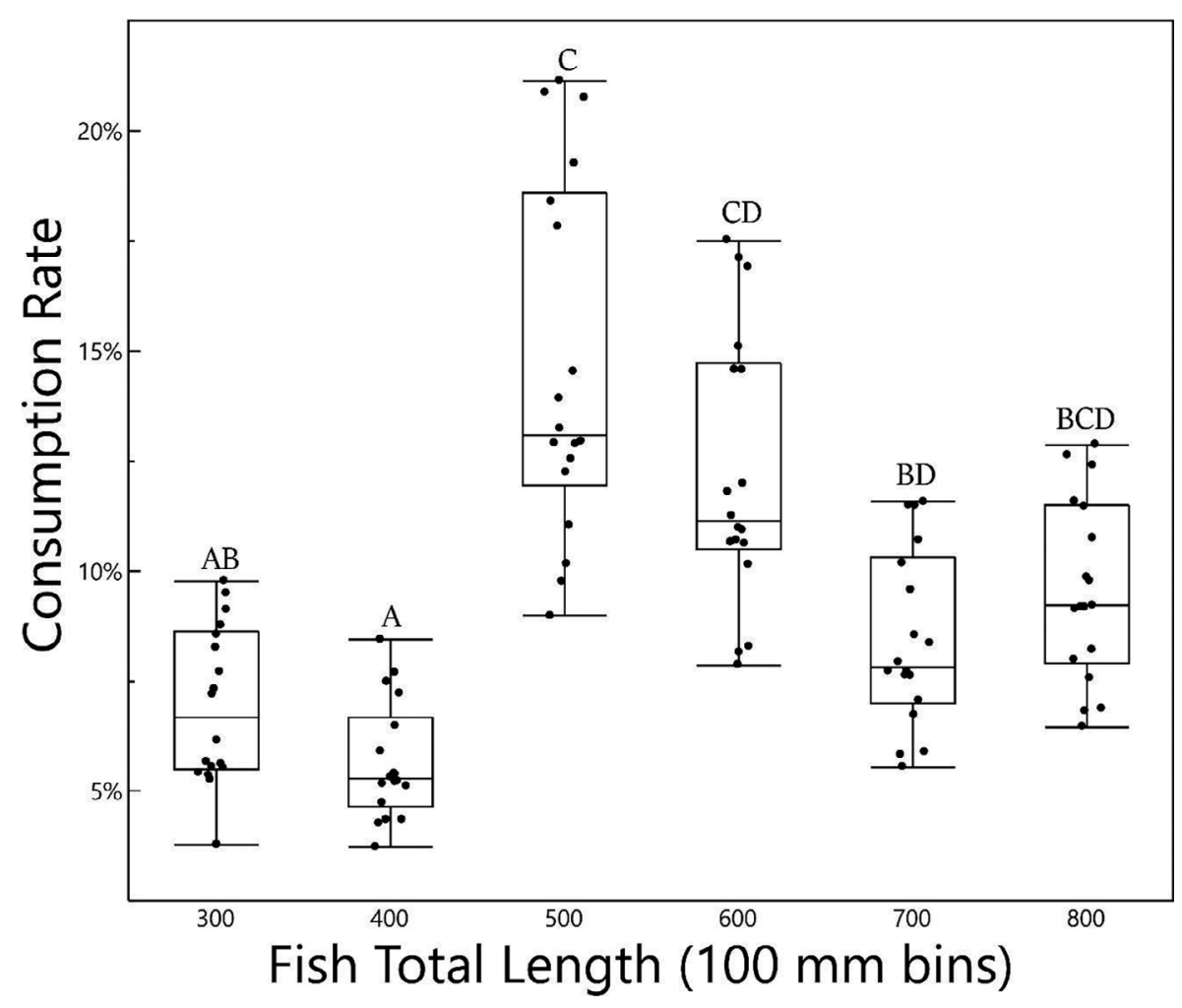

FIGURE 3. Lab estimates of maximum consumption rate (expressed as percent body weight per $24 \mathrm{~h}$ ) for Blue Catfish as it varies by fish total length $(\mathrm{mm})$. Estimates that do not share a letter (A-D above the boxes) differ significantly (Tukey's honestly significant difference: $P<0.05$ ). See Figure 2 for a description of the box plots.

motionless on the bottom of the tank while they digested their meal. These fish exhibited higher consumption rates than the others, though it is uncertain whether this is a length-based phenomenon or just individual feeding behavior. Interestingly, previous studies have shown that Blue Catfish undergo an ontogenetic shift from omnivory to piscivory near this size in the Rappahannock River (e.g., $500-600 \mathrm{~mm}$ TL is the "inflection point" in a logistic regression model of fish prey in the diet; Schmitt et al. 2019b). It is possible that Blue Catfish consume more when making this dietary transition, though more testing would be necessary to confirm this hypothesis.

Field estimates of maximum daily ration did not differ significantly from estimates obtained in the lab, and similarity across independent observations usually implies some degree of accuracy (Rice and Cochran 1984). Both lab and field experiments demonstrate that, in situations of peak feeding (e.g., maximum daily ration), consumption rates are approximately $8-9 \%$ of body weight per day at warmer water temperatures $\left(>15^{\circ} \mathrm{C}\right)$. These results should be interpreted as maximal feeding rates during the summer months as it is doubtful that Blue Catfish feed at these rates throughout the year. It is important to remember that Blue Catfish were starved for $72 \mathrm{~h}$ prior to each feeding trial and that each feeding trial only lasted $24 \mathrm{~h}$, which means that the fish really gorged themselves. Our field estimates of daily ration are likely more realistic as fish were subject to natural conditions (Jarre et al. 1991). Nonetheless, laboratory and field-derived estimates of maximum daily ration would complement information on peak feeding (e.g., vacuity indices or gut fullness indices) quite well (Kanou et al. 2005; Vinson and Angradi 2011) and could be applied to consumption models as an upper bound during times when high feeding intensity is observed in the field. Field estimates of daily ration were considerably lower (see below) than both lab and field estimates of maximum daily ration, and these estimates are likely more reflective of long-term, sustainable feeding rates (Bromley 1994).

Our estimates of daily ration are similar to estimates for Channel Catfish Ictalurus punctatus. Growth of Channel Catfish in aquaria occurs at $2-6 \%$ of body weight per day (bw/d; Andrews and Stickney 1972), which is very similar to our field estimates of Blue Catfish daily ration (2-5\% bw/d). Field studies for Channel Catfish have also produced similar estimates of daily ration $(2-8 \% \mathrm{bw} / \mathrm{d})$, though these rates decline to $1.23 \% \mathrm{bw} / \mathrm{d}$ at temperatures $<15^{\circ} \mathrm{C}$ (Kwak et al. 1992). We would anticipate a similar decline in feeding rates for Blue Catfish during the winter months. It is important to remember that our field studies 


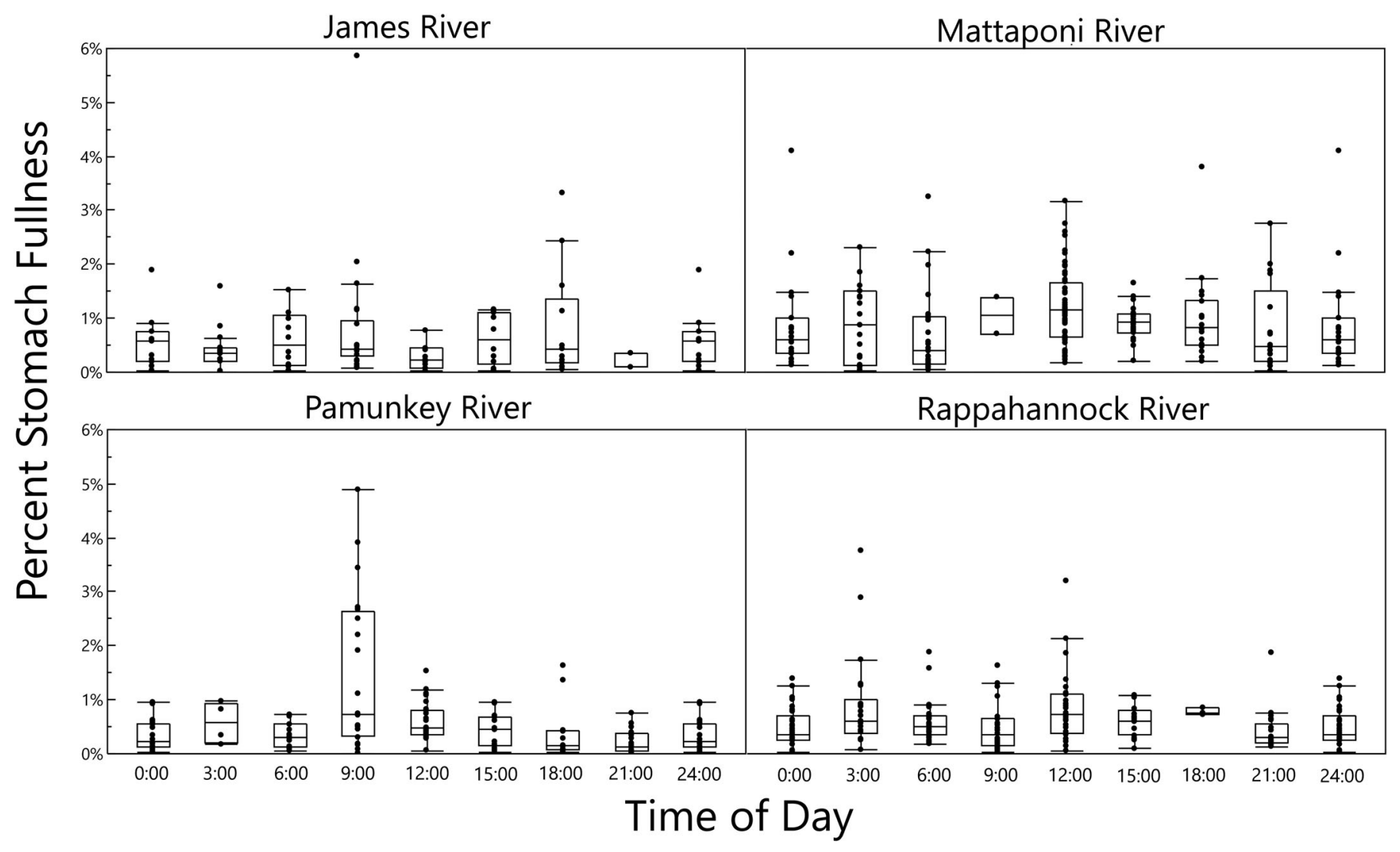

FIGURE 4. Stomach percent fullness (calculated as the wet weight of the stomach contents divided by the wet weight of the fish, times 100) throughout a 24-h period for 1,226 Blue Catfish captured on the James, Mattaponi, Pamunkey, and Rappahannock rivers in eastern Virginia. All diel feeding chronologies were completed during the month of August, and water temperatures ranged from $22.3^{\circ} \mathrm{C}$ to $29.6^{\circ} \mathrm{C}$. See Figure 2 for a description of the box plots.

TABLE 2. Calculations of daily ration $\left(C_{24}\right)$, maximum daily ration $\left(C_{\max }\right)$, and gastric evacuation rates $(R)$ based on 1,226 Blue Catfish stomachs collected during 24-h feeding chronologies on the James, Pamunkey, Mattaponi, and Rappahannock rivers in eastern Virginia.

\begin{tabular}{lcrcc}
\hline River & $\begin{array}{c}C_{24} \\
(\%)\end{array}$ & \multicolumn{1}{c}{$\begin{array}{c}C_{\max } \\
(\%)\end{array}$} & $\begin{array}{c}\text { Average } \\
R\end{array}$ & $\begin{array}{c}\text { Maximum } \\
R\end{array}$ \\
\hline James & 3.52 & 10.32 & 0.16 & 0.39 \\
Mattaponi & 2.27 & 4.34 & 0.06 & 0.08 \\
Pamunkey & 5.22 & 15.00 & 0.20 & 0.30 \\
Rappahannock & 3.39 & 5.37 & 0.13 & 0.15 \\
All rivers & 3.60 & 8.76 & 0.14 & 0.23 \\
\hline
\end{tabular}

were conducted at warm temperatures $\left(>22^{\circ} \mathrm{C}\right)$; thus, we would expect that feeding rates at cooler temperatures $\left(<15^{\circ} \mathrm{C}\right)$ would decline based on both our aquaria experiments (current study) and previous Channel Catfish studies (Kwak et al. 1992; Silverstein et al. 2001). Field estimates of Blue Catfish daily ration are also quite similar to another common predatory fish in these tidal rivers- the Largemouth Bass Micropterus salmoides. While diel feeding chronologies have never been completed for Largemouth Bass in Chesapeake Bay, studies from other systems have revealed that daily ration varies between $1.19 \%$ and $5.58 \%$ bw/d (Cochran and Adelman 1982), which is similar to our estimates for Blue Catfish $(2-5 \%$ bw/d).

In our field experiments, consistent diel feeding patterns were not apparent across all rivers. This is intuitive since much of the Blue Catfish population feeds on macrophytes and sessile bivalves like Asian clams Corbicula fluminea, which should be accessible regardless of the time of day (Schmitt et al. 2019a, 2019b). Increases in feeding may be associated with tidal cycles, as fish may wait for ideal flow conditions to leave resting locations to feed (Stoner 2004; Childs et al. 2008). There was some evidence of this as peak feeding occurred during the end of outgoing tide cycles for Blue Catfish in the James, Pamunkey, and Rappahannock rivers. The exception to this was the Mattaponi River, where peak feeding occurred towards the end of an incoming tide. It is important to note that low 


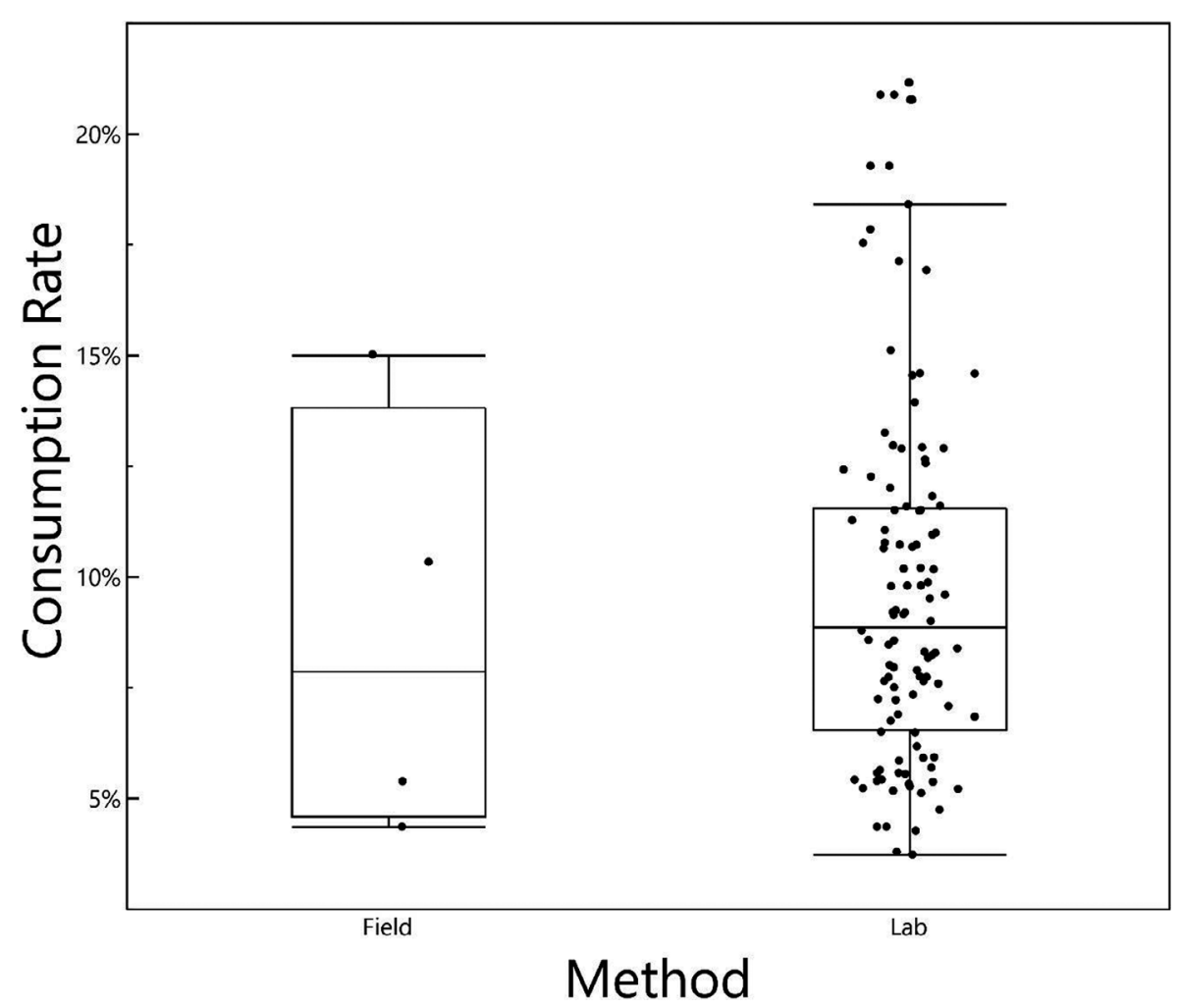

FIGURE 5. Maximum consumption rates (expressed as percent body weight per $24 \mathrm{~h}[\% \mathrm{bw} / 24 \mathrm{~h}]$ ) from the field and from the lab did not differ significantly (ANOVA: $P=0.63$ ). Mean maximum daily ration was $8.76 \%$ bw/24h in the field and $9.56 \%$ bw/24 h in the lab. See Figure 2 for a description of the box plots.

stomach fullness was observed during the Mattaponi River diel feeding chronology, and this general lack of activity may explain observed differences. Based on these findings, it appears that Blue Catfish prefer to feed past the midpoint of an outgoing tide cycle, though more research would be needed to assess this. Time of day varied, and may be less important, though peak stomach fullness occurred between 0900 and 1500 hours for all four rivers. Blue Catfish congregate in deep, flowing areas of rivers during late summer (J. D. Schmitt, personal observation), and light penetration is generally limited to the top $1-2 \mathrm{~m}$ of the water column in Chesapeake Bay (Dennison et al. 1993). Considering this, we hypothesize that Blue Catfish spend most of their time in darkness and foraging may be more influenced by other environmental factors (e.g., tides) than photoperiod, though more research is needed.

Consumption to biomass estimates were greater for small fish versus large fish, which is intuitive. Small Blue Catfish consume low-energy foods like vegetation and detritus, while large Blue Catfish are more piscivorous (Schmitt et al. 2019b). These differences in food habits require the inclusion of herbivory and detritivory terms in the model, which results in an increase in $Q / B$ ratios for small Blue Catfish. Logically, fish that eat low-energy foods like detritus will need to consume larger volumes of food than fish that eat energy-rich prey like Gizzard Shad (Gerking 1994). Blue Catfish $Q / B$ estimates ranged from 2.43 to 3.39 , which are similar to estimates for other benthic fish like Atlantic Cod Gadus morhua $(Q / B=2.59)$, Yellow Perch Perca flavescens $(Q / B=2.79)$, Lake Trout Salvelinus namaycush $(Q / B=2.89)$, Burbot Lota lota $(Q / B=3.29)$, and Common Dab Limanda limanda $(Q / B=$ 3.69; Palomares and Pauly 1998; Liao et al. 2005). The $Q /$ $B$ estimates for other catfishes vary broadly and are as low as 1.32 for African Sharptoothed Catfish Clarias gariepinus or as high as 22.07 for Bagrus docmak, which is a large, fast-growing catfish species native to central Africa (Palomares and Pauly 1998).

Studies on the impacts of invasive freshwater fish are rare (Garcia-Berthou 2007), and predatory impact can only be assessed once estimates of diet, consumption rates, and predator biomass are available (Ney 1990). The current study provides several estimates of Blue Catfish consumption rate, which will be critical for assessing ecological impacts of invasive Blue Catfish in the Chesapeake Bay and beyond (Schmitt and Orth 2015; Schmitt et al. 2017, 2019a, 2019b). The current study indicates that consumption rates vary considerably based on 
TABLE 3. Consumption to biomass $(Q / B)$ ratios were estimated for Blue Catfish in each of Virginia's major tidal rivers based on the aspect ratio $(A)$ of the caudal fin, mean annual water temperature $(T)$, average maximum weight $\left(W_{\infty}\right)$, and herbivory and detritivory dummy variables $(h$ and $d$, respectively). The $Q / B$ estimates were calculated separately for different size-groups of Blue Catfish based on river-specific shifts from omnivory to piscivory (Schmitt et al. 2019b).

\begin{tabular}{llllllll}
\hline River & Total length $(\mathrm{mm})$ & $A$ & $T\left({ }^{\circ} \mathrm{C}\right)$ & $h$ & $d$ & $W_{\infty}(\mathrm{kg})$ & $Q / B$ \\
\hline James & All lengths & 3.74 & 17.23 & 1 & 1 & 46.77 & 3.39 \\
& $<500$ & 3.74 & 17.23 & 1 & 1 & 46.77 & 3.39 \\
\multirow{3}{*}{ Pamunkey } & $>500$ & 3.74 & 17.23 & 0 & 0 & 46.77 & 2.46 \\
& All lengths & 3.74 & 17.41 & 1 & 0 & 30.11 & 2.96 \\
\multirow{3}{*}{ Mattaponi } & $<900$ & 3.74 & 17.41 & 1 & 0 & 30.11 & 2.96 \\
& $>900$ & 3.74 & 17.41 & 0 & 0 & 30.11 & 2.43 \\
& All lengths & 3.74 & 17.11 & 1 & 0 & 30.11 & 2.95 \\
Rappahannock & $>800$ & 3.74 & 17.11 & 1 & 0 & 30.11 & 2.95 \\
& $>800$ & 3.74 & 17.11 & 0 & 0 & 30.11 & 2.42 \\
& All lengths & 3.74 & 16.89 & 1 & 1 & 36.09 & 3.36 \\
& $<700$ & 3.74 & 16.89 & 1 & 1 & 36.09 & 3.36 \\
& $>700$ & 3.74 & 16.89 & 0 & 0 & 36.09 & 2.43 \\
\hline
\end{tabular}

temperature, size of fish, and river system. Furthermore, dietary patterns of Blue Catfish in these rivers exhibit strong spatiotemporal heterogeneity (Schmitt et al. 2019a, 2019b). Considering this, it is imperative that future assessments of predatory impact include variability in diets and consumption rates as extrapolations and sweeping generalizations across broad spatiotemporal scales will introduce error and provide unrealistic estimates. Consumption rate information can also be used for the construction of Ecopath models (Christensen et al. 2004) or for the development of a Blue Catfish bioenergetics model, which does not currently exist (Deslauriers et al. 2017). Blue Catfish are generalists in regard to both habitat and diet (Schmitt et al. 2019b); thus, further range expansion along the Atlantic slope is likely (Nepal and Fabrizio 2019). Moreover, Blue Catfish have been identified as potential invaders of the Laurentian Great Lakes, where impacts could be substantial (Howeth et al. 2016). Considering this, consumption estimates provided by this study are a timely addition to the scientific literature as invasive Blue Catfish will become more problematic in the future.

\section{ACKNOWLEDGMENTS}

We thank B. Peoples, J. Emmel, Z. Moran, J. Woodward, A. Mosely, H. Kim, H. Lee, B. Greenlee, J. Odenkirk, R. Willis, K. Johnson, A. Weaver, Y. Jiao, and S. Smith for their assistance over the course of the study. We thank the anonymous reviewers and editors whose comments resulted in a much better manuscript. Data collection was supported by the Virginia Department of Game and Inland Fisheries through a Sport Fish Restoration Grant from the U.S. Fish and Wildlife Service (contract \#2012-13705), and the senior author was partially supported through a fellowship from Virginia Sea Grant $(\mathrm{R} / 71856 \mathrm{~A})$. Any use of trade, product, or firm names is for descriptive purposes only and does not imply endorsement by the United States Government. There is no conflict of interest declared in this article.

\section{ORCID}

Joseph D. Schmitt (D) https://orcid.org/0000-0002-83544067

Corbin D. Hilling (iD https://orcid.org/0000-0003-40409516

Donald J. Orth (D) https://orcid.org/0000-0002-9236-0147

\section{REFERENCES}

Amundsen, P. A., and A. Klemetsen. 1988. Diet, gastric evacuation rates and food consumption in a stunted population of Arctic Charr, Salvelinus alpinus L., in Takvatn, northern Norway. Journal of Fish Biology 33:697-709.

Andersen, N. G. 2012. Influences of potential predictor variables on gastric evacuation in Atlantic Cod Gadus morhua feeding on fish prey: parameterization of a generic model. Journal of Fish Biology 80:595-612.

Andrews, J. W., and R. R. Stickney. 1972. Interactions of feeding rates and environmental temperature on growth, food conversion, and body composition of Channel Catfish. Transactions of the American Fisheries Society 101:94-99.

ASMFC (Atlantic States Marine Fisheries Commission). 2011. ASMFC approves resolution on non-native invasive catfish. Fisheries Focus 20(6):11. Available: http://www.asmfc.org/uploads/file/septOct2011.pdf. (February 2016).

Baumann, J. R., and T. J. Kwak. 2011. Trophic relations of introduced Flathead Catfish in an Atlantic river. Transactions of the American Fisheries Society 140:1120-1134.

Bodine, K. A., and D. E. Shoup. 2010. Capture efficiency of Blue Catfish electrofishing and the effects of temperature, habitat, and reservoir 
location on electrofishing-derived length structure indices and relative abundance. North American Journal of Fisheries Management 30:613-621.

Boisclair, D., and W. Leggett. 1988. An in situ experimental evaluation of the Elliott and Persson and the Eggers models for estimating fish daily ration. Canadian Journal of Fisheries and Aquatic Sciences 45:138-145.

Bonvechio, T. F., B. R. Bowen, J. S. Mitchell, and J. Bythwood. 2012. Non-indigenous range expansion of the Blue Catfish (Ictalurus furcatus) in the Satilla River, Georgia. Southeastern Naturalist 11:355-358.

Bourret, S. L., R. W. Tingley III, Y. Kanno, and J. C. Vokoun. 2008. Maximum daily consumption and specific daily metabolic demand of juvenile Flathead Catfish (Pylodictis olivaris). Journal of Freshwater Ecology 23:413-419.

Bowen, S. H. 1996. Quantitative description of the diet. Pages 513-532 in B. R. Murphy and D. W. Willis, editors. Fisheries techniques, 2nd edition. American Fisheries Society, Bethesda, Maryland.

Bromley, P. J. 1994. The role of gastric evacuation experiments in quantifying the feeding rates of predatory fish. Reviews in Fish Biology and Fisheries 4:36-66.

Bromley, P. J., and J. M. Last. 1990. Feeding in the trawl and the consequences for estimating food consumption in natural fish populations. International Council for Exploration of the Sea, C.M. 1990/G:35, Copenhagen.

Bunch, A. J., R. S. Greenlee, and E. M. Brittle. 2018. Blue Catfish density and biomass in a tidal tributary in coastal Virginia. Northeastern Naturalist 25:333-340.

CBP (Chesapeake Bay Program). 2017. CBP water quality database (1984-present). Available: https://www.chesapeakebay.net/what/down loads/cbp_water_quality_database_1984_present. (January 2018).

Cerino, D., A. S. Overton, J. A. Rice, and J. A. Morris Jr. 2013. Bioenergetics and trophic impacts of the invasive Indo-Pacific lionfish. Transactions of the American Fisheries Society 142:1522-1534.

Childs, A. R., P. D. Cowley, T. F. Næsje, A. J. Booth, W. M. Potts, E. B. Thorstad, and F. Økland. 2008. Do environmental factors influence the movement of estuarine fish? A case study using acoustic telemetry. Estuarine, Coastal and Shelf Science 78:227-236.

Christensen, V., and C. J. Walters. 2004. Ecopath with Ecosim: methods, capabilities and limitations. Ecological Modelling 172:109-139.

Christensen, V., C. J. Walters, and D. Pauly. 2005. Ecopath with Ecosim: a user's guide. University of British Columbia, Fisheries Centre Special Publication, Vancouver.

Clavel, J., R. Julliard, and V. Devictor. 2011. Worldwide decline of specialist species: toward a global functional homogenization? Frontiers in Ecology and the Environment 9:222-228.

Clavero, M., and E. García-Berthou. 2006. Homogenization dynamics and introduction routes of invasive freshwater fish in the Iberian Peninsula. Ecological Applications 16:2313-2324.

Cochran, P. A., and I. R. Adelman. 1982. Seasonal aspects of daily ration and diet of Largemouth Bass, Micropterus salmoides, with an evaluation of gastric evacuation rates. Environmental Biology of Fishes 7:265-275.

Dennison, W. C., R. J. Orth, K. A. Moore, J. C. Stevenson, V. Carter, S. Kollar, P. W. Bergstrom, and R. A. Batiuk. 1993. Assessing water quality with submersed aquatic vegetation. BioScience 43:86-94.

Deslauriers, D., S. R. Chipps, J. E. Breck, J. A. Rice, and C. P. Madenjian. 2017. Fish Bioenergetics 4.0: an R-based modeling application. Fisheries 42:586-596.

Elliott, J., and L. Persson. 1978. The estimation of daily rates of food consumption for fish. The Journal of Animal Ecology 47:977-991.

Fabrizio, M. C., T. D. Tuckey, R. J. Latour, G. C. White, and A. J. Norris. 2017. Tidal habitats support large numbers of invasive Blue Catfish in a Chesapeake Bay subestuary. Estuaries and Coasts 2017:1-14.
García-Berthou, E. 2007. The characteristics of invasive fishes: what has been learned so far? Journal of Fish Biology 71:33-55.

Gerking, S. D. 1994. Feeding ecology of fish. Academic Press, San Diego, California.

Graham, K. 1999. A review of the biology and management of blue catfish. Pages 37-49 in E. R. Irwin, W. A. Hubert, C. F. Rabeni, H. L. Schramm Jr., and T. Coon, editors. Catfish 2000: proceedings of the international ictalurid symposium. American Fisheries Society, Symposium 24, Bethesda, Maryland.

Grant, S. M., and E. Kott. 1999. Variation in field estimates of daily ration in young Yellow Perch. Journal of Fish Biology 54:396-403.

Green, R. H. 1993. Application of repeated measures designs in environmental impact and monitoring studies. Australian Journal of Ecology 18:81-98.

Hansen, P. C., T. B. Johnson, D. I. Schindler, and J. F. Kitchell. 1997. Fish bioenergetics model 3. Sea Grant Institute, University of Wisconsin, Technical Report WISCU-T-97-001, Madison.

Hayward, R. S., and E. Arnold. 1996. Temperature dependence of maximum daily consumption in White Crappie: implications for fisheries management. Transactions of the American Fisheries Society 125:132-138.

Helfman, G. S. 1993. Fish behaviour by day, night and twilight. Pages 479-512 in T. J. Pitcher, editor. Behaviour of teleost fishes. Chapman and Hall, London.

Heroux, D., and P. Magnan. 1996. In situ determination of food daily ration in fish: review and field evaluation. Environmental Biology of Fishes. 46:61-74.

Howeth, J. G., C. A. Gantz, P. L. Angermeier, E. A. Frimpong, M. H. Hoff, R. P. Keller, N. E. Mandrack, M. P. Marchetti, J. D. Olden, C. M. Romagosa, and D. M. Lodge. 2016. Predicting invasiveness of species in trade: climate match, trophic guild and fecundity influence establishment and impact of non-native freshwater fishes. Diversity and Distributions 22:148-160.

Hyslop, E. 1980. Stomach contents analysis - a review of methods and their application. Journal of Fish Biology 17:411-429.

Jarre, A., M. L. Palomares, M. L. Soriano, V. C. Sambilay, and D. Pauly. 1991. Some new analytical and comparative methods for estimating the food consumption of fish. ICES Marine Science Symposium 193:99-108

Johnson, J. H., and D. S. Dropkin. 1993. Diel variation in diet composition of a riverine fish community. Hydrobiologia 271:149-158.

Kanou, K., M. Sano, and H. Kohno. 2005. Ontogenetic diet shift, feeding rhythm, and daily ration of juvenile Yellowfin Goby Acanthogobius flavimanus on a tidal mudflat in the Tama River estuary, central Japan. Ichthyological Research 52:319-324.

Kwak, T. J., M. J. Wiley, L. L. Osborne, and R. W. Larimore. 1992. Application of diel feeding chronology to habitat suitability analysis of warmwater stream fishes. Canadian Journal of Fisheries and Aquatic Sciences 49:1417-1430.

Liao, H., C. L. Pierce, and J. G. Larscheid. 2005. An empirical model for estimating annual consumption by freshwater fish populations. North American Journal of Fisheries Management 25:525-532.

Lockwood, J. L., M. F. Hoopes, and M. P. Marchetti. 2013. Invasion Ecology. Wiley, Hoboken, New Jersey.

Mack, R. N., D. Simberloff, W. M. Lonsdale, H. Evans, M. Clout, and F. A. Bazzaz. 2000. Biotic invasions: causes, epidemiology, global consequences, and control. Ecological Applications 10:689-710.

Moser, M. L., and S. B. Roberts. 1999. Effects of nonindigenous ictalurids and recreational electrofishing on the ictalurid community of the Cape Fear River drainage, North Carolina. Pages 479-485 in E. R. Irwin, W. A. Hubert, C. F. Rabeni, H. L. Schramm Jr., and T. Coon, editors. Conservation, ecology, and management of catfish: the second international symposium. American Fisheries Society, Symposium 24, Bethesda, Maryland. 
Nepal, V., and M. C. Fabrizio. 2019. High salinity tolerance of invasive Blue Catfish suggests potential for further range expansion in the Chesapeake Bay region. PLOS (Public Library of Science) ONE [online serial] 14(11):e0224770.

Ney, J. J. 1990. Trophic economics in fisheries: assessment of demandsupply relationships between predators and prey. Reviews in Aquatic Sciences 2:55-81.

Orth, D. J., Y. Jiao, J. D. Schmitt, C. D. Hilling, J. A. Emmel, and M. C. Fabrizio. 2017. Technical report: dynamics and role of non-native Blue Catfish Ictalurus furcatus in Virginia's tidal rivers, project 2012-13705. Final Report to Virginia Department of Game and Inland Fisheries, Henrico.

Palomares, M. L. D., and D. Pauly. 1998. Predicting food consumption of fish populations as functions of mortality, food type, morphometrics, temperature and salinity. Marine and Freshwater Research 49:447-453.

R Core Team. 2018. R: a language and environment for statistical computing. R Foundation for Statistical Computing, Vienna. Available: https://www.R-project.org/.

Rice, J. A., and P. A. Cochran. 1984. Independent evaluation of a bioenergetics model for Largemouth Bass. Ecology 65:732-739.

Schloesser, R. W., M. C. Fabrizio, R. J. Latour, G. C. Garman, B. Greenlee, M. Y. Groves, and J. Gartland. 2011. Ecological role of Blue Catfish in Chesapeake Bay communities and implications for management. Pages 369-382 in P. H. Michaletz and V. H. Travinichek, editors. Conservation, ecology, and management of catfish: the second international symposium. American Fisheries Society, Symposium 77, Bethesda, Maryland.

Schmitt, J. D., Z. Moran, J. A. Emmel, A. Bunch, E. M. Hallerman, and D. J. Orth. 2017. Predation and prey selectivity by non-native catfishes on migrating alosines in an Atlantic slope estuary. Marine and Coastal Fisheries: Dynamics, Management, and Ecosystem Science [online serial] 9:108-125.

Schmitt, J. D., and D. J. Orth. 2015. First record of pughead deformity in Blue Catfish. Transactions of the American Fisheries Society 144:1111-1116.
Schmitt, J. D., B. K. Peoples, A. J. Bunch, L. Castello, and D. J. Orth 2019a. Modeling the predation dynamics of invasive Blue Catfish (Ictalurus furcatus) in Chesapeake Bay. U.S. National Marine Fisheries Service Fishery Bulletin 117:277-290.

Schmitt, J. D., B. K. Peoples, L. Castello, and D. J. Orth. 2019b. Feeding ecology of generalist consumers: a case study of Blue Catfish Ictalurus furcatus in the Chesapeake Bay, Virginia, USA. Environmental Biology of Fishes 102:443-465.

Shiah, F., and H. W. Ducklow. 1994. Temperature regulation of heterotrophic bacterioplankton abundance, production, and specific growth rate in Chesapeake Bay. Oceanography 39:1243-1258.

Silverstein, J. T., B. G. Bosworth, G. C. Waldbieser, and W. R. Wolters. 2001. Feed intake in Channel Catfish: is there a genetic component? Aquaculture Research 32:199-205.

Stoner, A. W. 2004. Effects of environmental variables on fish feeding ecology: implications for the performance of baited fishing gear and stock assessment. Journal of Fish Biology 65:1445-1471.

Temming, A., and N. G. Andersen. 1992. Modelling gastric evacuation in cod. A new gastric evacuation model applicable for the estimation of the daily ration of cod in the field. International Council for Exploration of the Sea, C.M. 1992/G:61, Copenhagen.

Vigg, S., T. P. Poe, L. A. Prendergast, and H. C. Hansel. 1991. Rates of consumption of juvenile salmonids and alternative prey fish by Northern Squawfish, Walleyes, Smallmouth Bass, and Channel Catfish in John Day Reservoir, Columbia River. Transactions of the American Fisheries Society 120:421-438.

Vinson, M. R., and T. R. Angradi. 2011. Stomach emptiness in fishes: sources of variation and study design implications. Reviews in Fisheries Science 19:63-73.

Warton, D. I., and F. K. Hui. 2011. The arcsine is asinine: the analysis of proportions in ecology. Ecology 92:3-10.

Zweifel, R. D., K. S. Hayward, and C. F. Rabeni. 1999. Bioenergetics insight into black bass distribution shifts in Ozark border region streams. North American Journal of Fisheries Management 19:192-197. 